4. A produção deve ser, sobretudo, dependente de materiais locais e destinada ao consumo local.

Estes quatro requisitos só podem ser satisfeitos se houver um enfoque regional de desenvolvimento $e$, mais ainda, se houver um esforço consciente para criar e.aplicar o que se pode denominar uma "tecnologia intermédia".

Para os países industrializados, o autor propõe como missão fundamental alcançar a pequenez dentro da organização grande, "de modo que cada pessoa possa abarcála na mente e imaginação".

Ser pequeno, observa Schumacher no epílogo do seu livro, é praticar quatro virtudes cardinais: prudência, jüstiça, fortitude e temperança.

Assim, talvez, o homem poderá construir um sistema de produção que não violente a natureza e um tipo de sociedade que não mutile o homem, cerne do pensamento do autor.

\section{Claude Machline*}

\footnotetext{
* Professor no Departamento de Administração da Produção e de Operações Industriais, da EAESP/FGV.
}

Faria, A. Nogueira de. Organizacão e métodos. Rio de Janeiro, Livros Técnicos e Científicos, 1982. 216 p. Brochura, sumário, índice remissivo, glossário, bibliografia, ilustrado.

Permito-me começar a resenha com a definição do objetivo do livro, extrarda do prefácio: "destinado a univer sitários - aumento de produtividade lógica (cartesiana) - tempos e movimentos - carga horária de 60 horas - administração, engenharia e economia".

Assim, em palavras-chave é possível ver para onde quer ir e como o autor deseja chegar aos fatos por meio dessa obra. Ele quer permitir que o jovem universitário raciocine dentro da lógica chegando a soluções de métodos de trabalho. O livro chega a atingir plenamente essa meta do autor. Tive uma vez a oportunidade de definir a administração por objetivos: "compra de um tailleur por uma mulher gorda que procura caber dentro por meio de dieta." Da mesma maneíra, o autor consegulu colocar dentro de poucas páginas uma figura da mulher gorda, a saber, a ciêncía de organização e métodos, atingindo bem o objetivo. Parabéns, portanto. O que foi cortado, o que está extensamente tratado é escolha do autor quem quiser mais procure o livro do mesmo autor Organização de empresas.

O livro comeca com o seguinte sumário: 1. Função de organização e métodos; 2 "Técnicas de levantamento; 3. Anállse do trabalho; 4. Racionalização e simplificação do trabalho; 5. Os métodos de trabalho; 6. Os postos de trabalho e a ambiência; 7 . Os centros de produção.

Ao resenhar o primeiro capítulo, devo considerá-lo claro e bem explicito, ressalvando o direito de criticar certos aspectos, a saber: o autor coloca "posição correta de $O$ \& $M$ no organograma" na figura 1.1, dando a impressão ao.incauto aluno de que esta é a única posição. Pelo organograma parece que a diretoria colegia- da é responsável e manda na presidência, que manda na superintendência - sistema GM, de difícil aplicação em certas empresas brasileiras. A figura 1.2 parece-me ser de empresa muito grande, portanto, "modelo completo". As definições de eficácia, eficiência e produtividade no glossário estão certas, só que de mais difícil memorização que incisivas generalizacões, tendo em vista o fim didático do livro. A bibliografia do capítulo em português é muito boa.

O capítulo 2 é um primor, mostrando o profundo conhecimento do autor no ássunto. Posso não estar de acordo com certas perguntas do questionário apresentado, mas este é completo - quem não gostar de algo, pode cortá-lo. Também se nota no autor a vontade de evitar os métodos Dasp de administração pública como procedimentos exclusivos que levam ao resultado. Fiz uma experiência, aplicando integralmente o referido método, e o resultado foi muito bom. A aplicação é demorada, mas talvez seja isso exatamente o que o técnico deseja, em 1982, ano de dificuldades generalizadas. Agora, quem óbservar que o resultado da "tabulação" (ver glossário) pode dar em algo diferente do esperado - o mesmo questionário pode dar origem a duas interpretações na tabulação; donde, me permito acrescentar que são necessárias indicações na pesquisa de opinião, como o autor quer fazer para a correlação de certas perguntas, para identificar o significado da resposta. Mas, antes de tudo, o capítulo permite trabalhar dentro de regras que levam a resultados úteis, portanto, é excelente.

No terceira capítulo - Análise do trabalho - temos um bom resumo, faltando uma "divisão do trabalho" em processos, operações, elementos etc., antes de entrar em therbligs, e uma definição bivalente de operação e processo no glossário. Quem precisar, que recorra à bibliografia do capítulo, que dá indicações suficientes. Como engenheiro defino operação como "parte de processo, existente em muitos processos, tanto burocráticos quanto industriais, por exem"plo, 'contabilização" ou 'usinagem'" 
- capítulo de racionalização e simplificação do trabalho permanece no mesmo bom nível do terceiro capítulo - é definitivamente representativo de um desenvolvimento lógico, e pode ser aplicado. Chamaria, no entanto, a atenção dos futuros usuários para 0 fato de que o transporte e as danosas movimentações (transporte internol devidas ao leiaute falho podem dar resultados surpreendentes na diminuição de custos e na racionali. zação.

Assim, recomendo duas inclusões na bibliografia deste ou dos demais capítulos até o de número $7: 0$ livro de Moura (Reynaldo) sobre movimentação e o livro de Muther sobre leiaute; o primeiro genuinamente nacional, o segundo em tradução da Editora Edgard Blücher, sob o título Planejamento do layout.

No quinto capítulo nada tenho a adicionar ou tirar, já que as traduções para insight ou brainstorming, usadas pelo autor, não são generalizadas e, conseqüentemente, nem sempre reconhecidas. Gostaria, no entanto, de acrescentar na bibliografia ao menos um livro em inglês, o de De Bono, autor inglês $e$ inventor do lateral thinking, criatividade por intuição, dedução e raciocínio seqüencial.

O sexto capítulo é uma boa introdução à ergonomia. Como o campo desta é imenso, o autor teve de restringir a cobertura, o que conseguiu com pleno sucesso. Realmente, para fins de ensino de três grupos tão diversos, como engenharia, administração e economia, o termo médio encontrado foi perfeito. Só não gostei do título - 0 posto de trabalho e a ambiência - pois é muito restritivo: a ambiência não inclui ritmo, fadiga etc., tudo tratado no capítulo.

O sétimo capítulo não consegue uma síntese tão boa quanto o sexto, pois a matéria é extensa demais. Os livros necessários para leiaute e movimentação já foram mencionados anteriormente e devem, neste capítulo, servir de base para estudos mais aprofundados, ao menos para engenheiros e administradores. Finalmente, uma observação sobre a palavra "localgrama" em lugar de leiaute (empresa) para distingui-la de leiaute (publicida- de). Nunca encontrei a confusão que o autor diz que existe entre os dois conceitos de leiaute.

Resumidamente: gostei do livro, vou usá-lo como leitura principal em cursos de produção (de 45 horas) e espero que os meus alunos gostem tanto quanto eu.

Boa apresentação gráfica, como é comum na LTC.

Kurt Ernst Weil ${ }^{*}$

* Professor no Departamento de Administração da Produção e de Operações Industriais, da EAESP/FGV.
Fernandes, Florestan. A ditadura em questão. São Paulo, T. A. Queiroz, 1982. 164p.

Minha geração, que está beirando os 30 anos, pouco ou nenhum contato teve com a pessoa ou com as obras do sociólogo Florestan Fernandes. Evidentemente, seu afastamento compulsório da Universid́ade de São Paulo no final dos anos 60 (onde ensinava e pesquisava a partir de 1945) contribuiu para que ficasse "esquecido" pelos colegas e discípulos granjeados ao longo de quase três décadas de atividades intelectuais das mais intensas. Eu mesmo, em cursos regulares de graduação e de pós-graduação, li, juntamente com centenas de outros colegas, apenas os capítulos iniciais dos Fundamentos empíricos da explicação sociológica, já há um bom tempo. Suas demais obras ficaram meio que congeladas e não figuravam em nenhuma bibliografia. Em 1977, devorei toda a segunda parte de seu A sociologia no Brasil (Vozes, 1977) e, mais recentemente, acabei não lendo A Revolução Cubana (T. A. Queiroz, 1979). Assim, este $A$ ditadura em questão, seu 30 ? livro, tem para mim um sabor especial, algo como um ajuste de ponteiros com o mestre.

A capa em fundo branco, com um pulso verde fechado (unha de polegar amarela), me lembra imediatamente o "Incrível Hulk" - bravo, indignado, com muita raiva. Se se começa a ler o denso, engajado e tenso trabatho de Florestan, tem-se a impressão (aliás plenamente justificada) de que a manopla verde vai dar um sopapo na ditadura. Mas vamos por partes.

A linguagem do professor ainda permanece árida (embora bem mais fluente do que aquela dos Fundamentos empiricos...), suas afirmacõ̃es não primam pela concisão (os parágrafos de duas e três páginas seguidas são freqüentes) e sua retórica é permeada de figuras (tipo "a dita. dura destampou a panela e regulou o fogo de acordo com sua própria culinária" - p.66). Entretanto, é fácil 